\title{
Obesity influences propranolol pharmacokinetics in patients undergoing coronary artery bypass grafting employing cardiopulmonary bypass
}

\author{
Valéria Adriana Pereira', Maria José Carvalho Carmona², Célia Etsuco Kobayashi Omosako², \\ José Otávio Costa Auler Júnior ${ }^{2}$, Silvia Regina Cavani Jorge Santos ${ }^{1 *}$
}

'Departamento de Farmácia, Faculdade de Ciências Farmacêuticas, Universidade de São Paulo, 2 InCor-Instituto do Coração Hospital das Clinicas, Faculdade de Medicina da Universidade de São Paulo

*Correspondence:

S.R.C.J. Santos

Laboratório de Farmacologia

Terapêutica, Departamento de

Farmácia

FCF/USP

Av. Prof. Lineu Prestes, 580 05508-900

Sao Paulo, Brazil.

E-mail: pharther@usp.br.
Propranolol plasma levels and kinetic disposition may be altered by hypothermic cardiopulmonary bypass $(C P B-H)$. We investigated the potential influence of obesity on propranolol pharmacokinetics in patients undergoing coronary artery bypass grafting employing CPB-H. Fifteen patients, receiving propranolol perorally pre- (10$40 \mathrm{mg}$, 2-3 times a day) and post-operatively (10 mg, once a day) were distributed in two groups, based on body mass index (BMI), in obese ( $n=9$, BMI: mean $\left.29.4 \mathrm{~kg} / \mathrm{m}^{2}\right)$ and non-obese ( $n=6$, BMI: mean $\left.24.8 \mathrm{~kg} / \mathrm{m}^{2}\right)$. A serial of blood samples was collected at the pre- and post-operative periods at time dosing interval $(\tau)$; propranolol plasma levels were measured one day before and after surgery using a high performance liquid chromatographic procedure described previously. PK Solutions software 2.0 was applied to obtain pharmacokinetic parameters. No changes on kinetic parameters as biological half-life $\left(t_{1 / 2}, p=0.0625, N S\right)$, volume of distribution $(\mathrm{Vd} / \mathrm{F}, \mathrm{p}=0.8438, \mathrm{NS})$ and plasma clearance $\left(C L_{T} / F, p=0.1563, N S\right)$ were obtained for the non-obese patients, while a prolongation of $t_{1 / 2}(3.2$ to $11.2 \mathrm{~h}, \mathrm{p}<0.0039)$, an increase on $\mathrm{Vd} / \mathrm{F}(3.0$ to $7.7 \mathrm{~L} / \mathrm{kg}, p<0.0039)$ and reduction on $C L_{T} / F(11.3$ to $9.2 \mathrm{~mL} / \mathrm{min} . \mathrm{kg}, p<0.0391)$ were obtained in the post-operative period for obese patients. Pharmacokinetic data could justify propranolol plasma concentrations in obese patients higher than in non-obeses, after surgery.

\section{INTRODUCTION}

Propranolol, a nonselective beta-adrenergic blocking agent, is an usual drug prescribed for treatment of arterial hypertension, angina pectoris, and cardiac arrhythmia. It is totally absorbed after the oral dose, shows a first-pass effect and consequently a low fraction of dose absorbed reaches the systemic circulation as unchanged drug. The drug highly distributed, also binds to plasma proteins, with approximately $90 \%$ of the circulating drug 
bounded mainly to plasma $\alpha 1$-acid glycoprotein (Sager $e t$ al., 1989). Additionally, this lipophilic drug is extensively biotransformed by the liver, with most inactive metabolites excreted in the urine.

High variability in pharmacokinetics of propranolol reported in normal subjects and also in patients, affecting mainly distribution and elimination of drug (Jones et al., 1976; Boudoulas et al., 1978; McAllister et al., 1979; McAllister et al., 1980; Hoffman, Lefkowitz, 1996) associated to different response between individuals related to sympathetic tone (PDR, 1998) could explain the wide range on plasma levels noted at therapeutic doses required to reach clinical efficacy.

Propranolol plasma levels appear to be altered in surgical patients following coronary bypass grafting with mild hypothermic $\left(\sim 32{ }^{\circ} \mathrm{C}\right)$ cardiopulmonary bypass, CPB-H, (McAllister et al., 1979; Holley et al., 1982; Buylaert et al., 1989). Consequently doses could be adjusted to avoid undesirable consequences in the postoperative period.

On the other hand, drug prescription for obese patients is not easy, since changes in dosage scheme, based on pharmacokinetic data in normal subjects, could induce errors (Cheymol et al., 1997). Discussion remains, considering the influence of obesity on kinetics of propranolol reported previously and also the pharmacokinetic change after cardiopulmonary bypass in non-obese patients.

Then, a study protocol was designed to investigate the influence of CPB-H on the kinetic disposition of propranolol in obese patients with coronary heart disease indicated for myocardial revascularization with $\mathrm{CPB}$ under moderate hypothermia.

\section{MATERIAL AND METHODS}

Fifteen coronarian patients scheduled for myocardial revascularization with moderate hypothermic $\left(\sim 32{ }^{\circ} \mathrm{C}\right)$ cardiopulmonary bypass were included in the protocol. The Institutional Ethical Committee (N: 1414/ 98/109) previously approved this protocol, and all of the patients provided written informed consent to participate in the study. In addition, all procedures were performed in accordance with institutional guidelines. Ambulatorial patients (unstable angina) under chronic treatment receiving propranolol (10-40 $\mathrm{mg}$ PO two or three times a day, for several months) were included. They were distributed into two groups, obese patients $(n=9)$ and nonobese patients $(\mathrm{n}=6)$, based on body mass index (BMI; reference for obesity $>25 \mathrm{~kg} / \mathrm{m}^{2}$ ); additionally body weight deviation, expressed as percentage of ideal body weight (reference for obesity $>10 \%$ ) was also compared to BMI for all patients.

Characteristics of subjects of both groups, expressed as the mean (CI 95), are as follows. Obese patients: age: 57 (52-63) yr; body weight: 83 (75-91) kg; height: 168 (161-174) cm; body mass index (BMI): 29.4 (27-32) $\mathrm{kg} / \mathrm{m}^{2 ;}$ body weight deviation: 29.2 (14-44)\%; body surface area (BSA): $1.9(1.8-2.0) \mathrm{m}^{2}$. Non-obese patients: age: 61 (56-65) yr; body weight: $71(66-76) \mathrm{kg}$; height: 169 (164-173) cm; BMI: 24.8 (24-25) kg/m²; body weight deviation: 3.1 (0.7-5.5) \%; and BSA: $1.8(1.7-1.9) \mathrm{m}^{2}$.

Selected coronary patients were in the infirmary for routine examination before surgery. A day before the surgical intervention, in the morning, after drug intake, pre-operative blood sampling was performed at time dose interval (zero, 2, 4, 6, and $8 \mathrm{~h}$ or $12 \mathrm{~h}$ ) for pharmacokinetics. Then, early next morning, all patients were submitted to cardiac surgery with CPB - H. At the first post-operative day, they received propranolol PO dose, 10 mg once a day; blood samples were collected again at time dose interval (zero, 2, 4, 6, 8, 12 and $24 \mathrm{~h}$ ) for pharmacokinetics.

Propranolol plasma levels were determined by high performance liquid chromatography with fluorescence detection (HPLC-F), as reported previously by Pereira et al. (2000). Twenty-five microliters of internal standard (verapamil $2.5 \mu \mathrm{g} /$ assay), $200 \mu \mathrm{L}$ of $1.25 \mathrm{~N} \mathrm{NaOH}$, and 3 $\mathrm{mL}$ of dichloromethane were added to $200 \mu \mathrm{L}$ of plasma. Mixture was vortexed for $1 \mathrm{~min}$ and centrifuged for 30 $\mathrm{min}$ at $3000 \mathrm{rpm}$. Then, the organic phase was transferred and evaporated to dryness, and the residue was dissolved with $100 \mu \mathrm{L}$ of mobile phase $(0.38 \mathrm{M}$ acetate buffer $\mathrm{pH}$ 5.0:acetonitrile 65:35, v/v) and injected into the HPLC system using analytical column (NovaPak C18 $150 \mathrm{x}$ $3.9 \mathrm{~mm}, 5 \mu \mathrm{m}$, Waters Assoc., Mildford, USA). Peaks were monitored using a fluorescence detector setted at 290 $\mathrm{nm} / 358 \mathrm{~nm}$, excitation/emission as described previously.

PK Solutions 2.0 software for pharmacokinetics was applied to data obtained. Area under the curve $\left(\mathrm{AUC}_{\mathrm{T}}\right)$ and kinetic parameters obtained from plasma curve decay: apparent volume of distribution $(\mathrm{Vd} / \mathrm{F})$, and drug elimination measured through total body clearance $\left(\mathrm{Cl}_{\mathrm{T}} / \mathrm{F}\right)$, and biological half-life $\left(\mathrm{t}_{1 / 2}\right)$, at the pre-operative and postoperative periods were estimated.

The GraphPad InStat ${ }^{\mathrm{TM}}$ (GraphPad Software, San Diego, USA) was applied to the data obtained for statistics. Tests for paired and unpaired data were applied for statistical analysis and data reported in the present study was expressed as median, mean and CI95 range. Non parametric tests were applied and a significance $\mathrm{p}<0.05$ was considered. 


\section{RESULTS AND DISCUSSION}

\section{Pharmacokinetics of propranolol in obesity: non-obese versus obeses}

At the pre-operative period, a slight but non significant reduction was obtained in plasma clearance and volume of distribution when obese patients were compared to the controls, remaining unchanged the biological half-life. Plasma levels comparing obese and non-obese patients in this period are showed in Figure 1.

Similar reductions in these parameters were reported previously for obese individuals versus normal subjects after IV single dose of propranolol (Cheymol et al., 1987; Poirier et al., 1990; Cheymol et al., 1997). The modification of regional blood flow was proposed by those authors to explain the altered tissue diffusion of drug in the obese subjects. Additionally, they reported that lipophilic beta-adrenoceptor blockers as propranolol seem to diffuse less into adipose than into lean tissues, based also on several electrical forms present (i.e. cations, neutral forms, or zwitterions) at physiological $\mathrm{pH}$, that contribute to their tissue distribution in both obese and lean subjects. The tissue distribution in obese patients could be restricted by the sum of hydrophobic forces and hydrogen bonds they elicit with macromolecules in lean tissues (Cheymol et al., 1997).

According to Belfrage (1978), in a previous study carried out in dogs, changes in the vascular resistance of adipose tissues were induced by the activation of the sympathetic nerves and noradrenaline administration, as a consequence of the combined results of alpha-adrenergic vasoconstriction and beta-adrenergic vasodilatation. The author also reports that propranolol and practolol potentiate vasoconstriction induced by noradrenaline administration or sympathetic nerve stimulation in dogs.

Therefore, it is possible that a vasoconstriction by beta-blocking drugs in adipose tissue of humans could restrict the distribution of a highly lipid soluble substance such as propranolol without modifying the distribution of hydrophilic drugs as sotalol, because of its weak lipid solubility (Poirier et al., 1990).

By the other hand, the plasma clearance of a substance with a high hepatic extraction ratio, such as propranolol, depends on hepatic blood flow rather than on the metabolic activity of liver in subjects with normal liver function (Weiss et al., 1978). Additionally, as commented by Poirier et al.(1990), the decrease in total body plasma clearance of propranolol obtained by Braillon and Capron, (1983) as a consequence of histological hepatic alterations, could explain the reduction of metabolic capacity in obese subjects, in spite of routine liver function tests show to be unaltered in those subjects (Braillon et al., 1985). Therefore, they proposed that these modifications could be due mainly to changes in tissue perfusion in obese individuals (Braillon, Capron, 1983; Braillon et al., 1985)

\section{Pharmacokinetics of propranolol in non-obese patients: post- versus pre-operative - influence of $\mathrm{CPB}-\mathrm{H}$}

Pharmacokinetics of propranolol in non-obese patients remains unchanged after CPB-H as described in

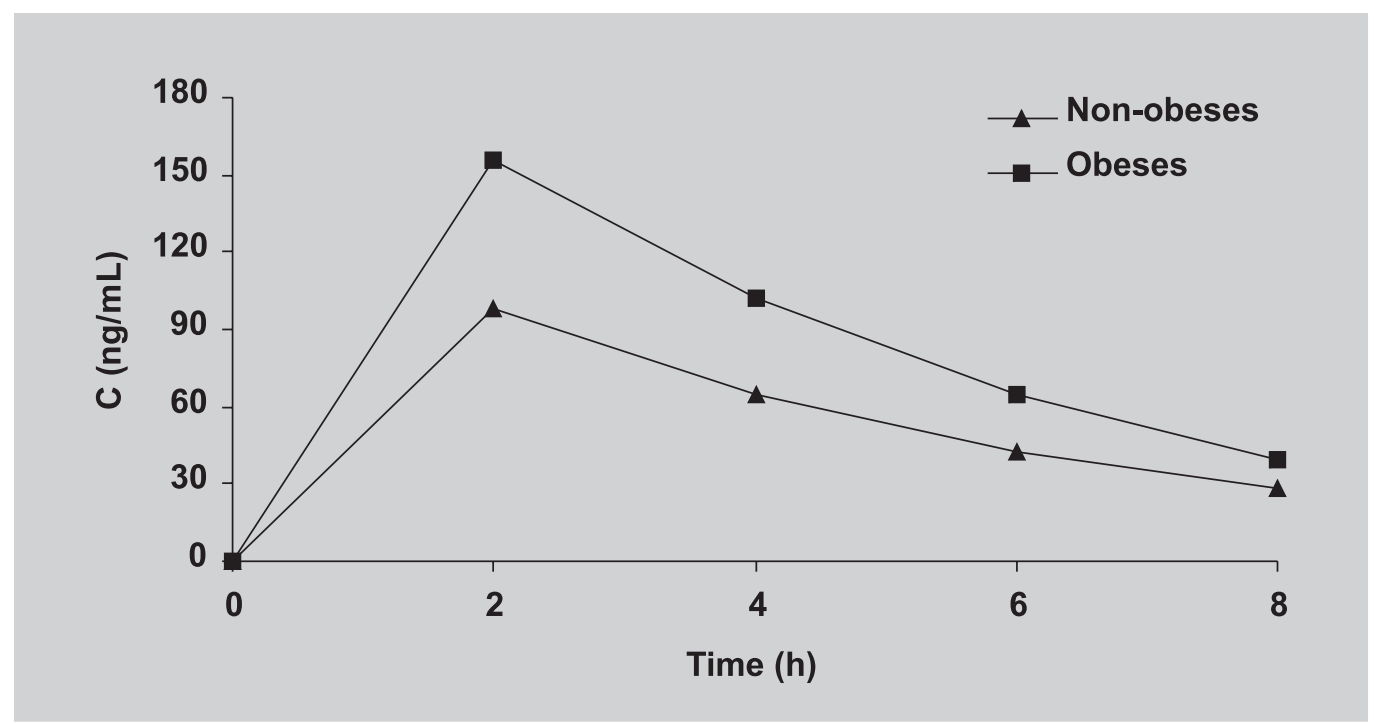

FIGURE 1 - Propranolol plasma levels (means) at the pre-operative period in patients: obeses, $\mathrm{n}=9$ versus non-obeses, $\mathrm{n}=6$. 
Table 1. The high interindividual variation of plasma clearance, half-life and volume of distribution obtained in the present study showing non significant alterations, for non-obese patients after surgery could be supported by pharmacokinetic data reported previously for propranolol in healthy volunteers and also in patients after intravascular or peroral administration of single or chronic doses (Jones et al., 1976; Boudoulas et al., 1978, McAllister et al., 1979; McAllister et al., 1980; Hoffman, Lefkowitz, 1996; Cheymol et al., 1997).

\section{Obeses - influence of CPB-H}

In parallel, at the first post-operative day, after the tracheal extubation and drug intake (propranolol PO dose,
$10 \mathrm{mg}$ once a day); significant alterations in the pharmacokinetics were obtained in obese patients, Table I. Plasma clearance was reduced from $11.3 \mathrm{~mL} / \mathrm{min} . \mathrm{kg}$ to $9.2 \mathrm{~mL} / \mathrm{min} . \mathrm{kg}, \mathrm{p}=0.0391$ ), while volume of distribution was increased from $3.0 \mathrm{~L} / \mathrm{kg}$ to $7.7 \mathrm{~L} / \mathrm{kg}$, $(\mathrm{p}=0.0039)$; when periods before and after surgery were compared. Elimination half-life was prolonged by 3.5 fold (3.2 vs $11.2 \mathrm{~h}, \mathrm{p}=0.0039$ ); then, it could be justified once nonproportional alterations were obtained in plasma clearance and volume of distribution after CPB-H.

Plasma drug concentration at dose interval in the post-operative period for both groups are illustrated in Figure 2.

It is well known that a $30 \%$ reduction of organ perfusion after cardiac surgery employing CPB can

TABLE I - Influence of CPB-H on pharmacokinetics of propranolol in obese patients

\begin{tabular}{lccc}
\hline $\begin{array}{l}\text { Kinetic Parameters } \\
\text { (reference data 1*) }\end{array}$ & \multicolumn{2}{c}{ Non-obese patients - CONTROL, median (CI95\%) mean } \\
Pre- & $3.1(2.0-7.0) 4.5$ & $7.6(4.0-11.0) 7.5$ & P \\
\hline $\mathrm{t}_{1 / 2}(3.9+0.4 \mathrm{~h})$ & $17.2(7.9-35.1) 21.5$ & $9.0(6.4-14.9) 10.7$ & 0.0625 \\
$\mathrm{Cl} / \mathrm{F}(16+5 \mathrm{~mL} / \mathrm{min} . \mathrm{kg})$ & $4.6(1.1-13.9) 7.5$ & $5.9(3.0-10.9) 6.9$ & 0.1563 \\
$\mathrm{Vd} / \mathrm{F}(4.3+0.6 \mathrm{~L} / \mathrm{kg})$ & \multicolumn{4}{c}{ Obese patients - median (CI95\%) mean } \\
\hline \multicolumn{4}{c}{0.8438} \\
\hline $\mathrm{t}_{1 / 2}(3.9+0.4 \mathrm{~h})$ & $3.2(3.0-5.0) 4.0$ & $11.2(10.2-17.8) 14.0$ & 0.0039 \\
$\mathrm{Cl} / \mathrm{F}(16+5 \mathrm{~mL} / \mathrm{min} . \mathrm{kg})$ & $11.3(7.3-19.6) 13.4$ & $9.2(5.4-12.0) 8.7$ & 0.0391 \\
$\mathrm{Vd} / \mathrm{F}(4.3+0.6 \mathrm{~L} / \mathrm{kg})$ & $3.0(1.3-9.4) 5.4$ & $7.7(5.2-15.9) 10.6$ & 0.0039 \\
\hline
\end{tabular}

Statistics: Wilcoxon's Test, post- versus pre-operative periods; significance level: $p<0.05 ;{ }^{*}$ Reference values, Hardman J.G. et al. (1996).

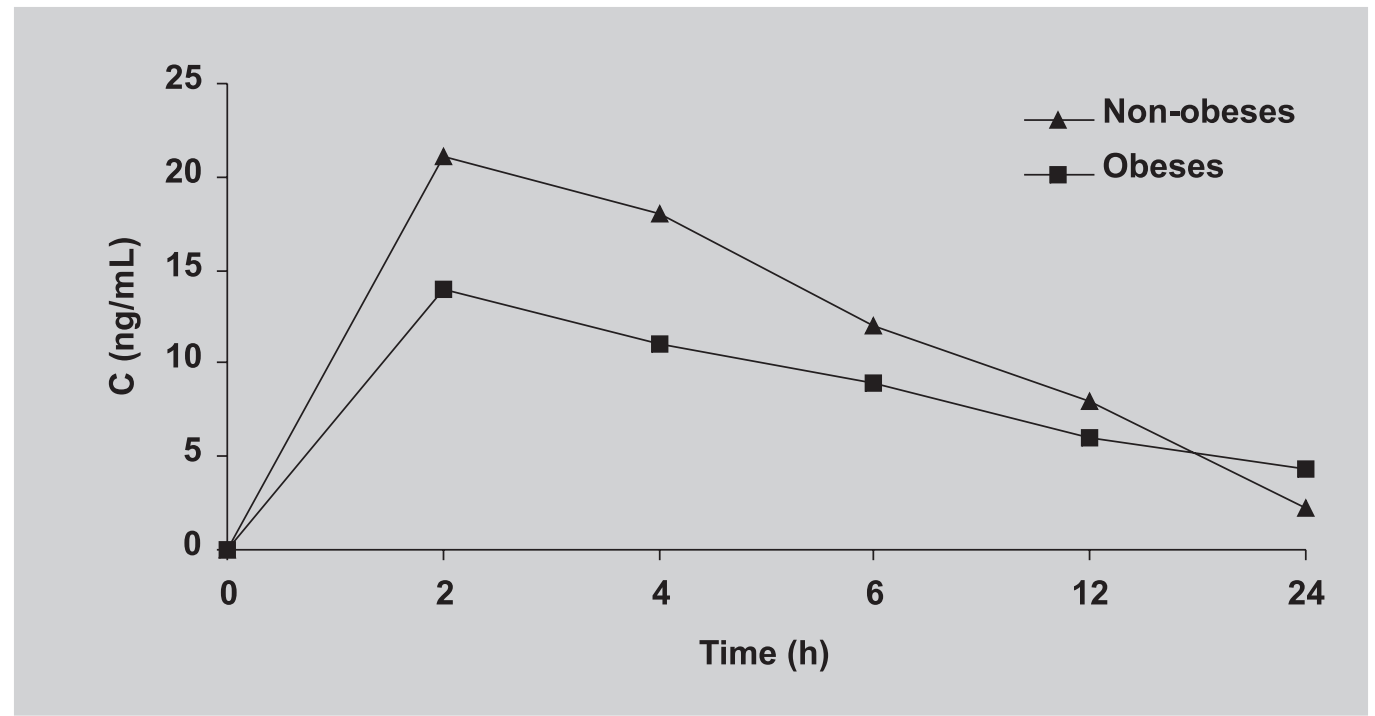

FIGURE 2 - Propranolol plasma levels (means) at the post-operative period in patients: obeses, $\mathrm{n}=9$ versus non-obeses, $\mathrm{n}=6$. 
influence the elimination of drugs by the liver and kidneys, with kinetic consequences such as reduction on total body clearance and prolongation of elimination halflife (Babka, Pifarré, 1977; Fellander et al., 1996; Holley et al., 1982). In addition, drug distribution and its metabolism by the liver are altered by the systemic cooling during the hypothermic conditions decreasing volume of distribution and also plasma clearance as demonstrated in previous studies, (Babka, Pifarré, 1977; McAllister et al., 1979; Fellander et al., 1996).

Therefore, in obese post surgical patients followed coronary bypass grafting with mild hypothermia $\left(32{ }^{\circ} \mathrm{C}\right)$ associated to cardiopulmonary bypass, the pharmacokinetics of propranolol could be influenced by the increase of diffusion of the lipophilic beta blocking agent to tissues. These findings could be due to a lower restriction on the diffusion of this drug to the tissues in the obese subjects obtained after surgery, justifying the increase in volume of distribution and the prolongation of biological half-life.

It means that CPB-H could affect the equilibrium of several electrical forms present as a function of physiological $\mathrm{pH}$ after surgery contributing to their tissue distribution in a higher extension in obese than lean subjects investigated in the present study. Consequently, propranolol tissue distribution in obese patients could be restricted, before surgery, by the sum of hydrophobic forces and hydrogen bonds as reported previously by Cheymol et al.(1997). Changes obtained in drug distribution and elimination for obese patients after CPB-H suggest lower response to vasoconstriction induced by noradrenaline administration or sympathetic nerve stimulation potentiated by propranolol that could justify its influence on the pharmacokinetics in obese patients after surgery.

Data obtained indicate that $\mathrm{CPB}-\mathrm{H}$ affects the pharmacokinetics of propranolol by increase of the extension of distribution and prolongation of biological half-life in obese patients, while plasma clearance was reduced in a lower extension. Pharmacokinetic data could justify propranolol plasma concentrations in obese patients higher than in non-obeses, after surgery.

\section{RESUMO}

\section{Influência da obesidade na farmacocinética do propranolol em pacientes submetidos à revascularização do miocárdio com circulação extracorpórea}

As concentrações plasmáticas e a disposição cinética do propranolol podem ser alteradas pela circulação extracorpórea (CEC). Investigou-se a influência da obe- sidade na farmacocinética do propranolol em pacientes submetidos à revascularização do miocárdio empregando a CEC. Investigaram-se quinze pacientes, recebendo cronicamente propranolol no pré- $(10-40 \mathrm{mg}, 2$ a 3 vezes ao dia $P O)$ e no pós-operatório (10 mg, 1 vez ao dia) sendo os mesmos distribuidos em dois grupos: obesos $(n=9$, média 29,4) $\mathrm{kg} / \mathrm{m}^{2}$; e não-obesos ( $n=6$, média $24,8 \mathrm{~kg} / \mathrm{m}^{2}$ ). Colheram-se amostras seriadas de sangue nos periodos pré- e pós-operatório ( $\tau$ ); determinaram-se as concentrações plasmáticas do propranolol através da cromatografia líquida de alta eficiência. Aplicou-se o software PK Solutions 2.0 para estimativa dos parâmetros cinéticos. Não se registrou alteração na farmacocinética do propranolol avaliada através dos parâmetros meiavida biológica $\left(t_{1 / 2}\right)$, volume de distribuição aparente $(\mathrm{Vd} / \mathrm{F})$ e depuração plasmática $\left(C L_{T} / F\right)$ no grupo de pacientes não-obesos, enquanto prolongamento relevante da $t_{1 / 2}(3,2$ para $11,2 \mathrm{~h}, \mathrm{p}<0,0039)$, aumento no $\mathrm{Vd} / \mathrm{F}$ (3,0 para 7,7 L/kg, $p<0,0039)$ e redução no $C L_{T} / F(11,3$ para $9,2 \mathrm{~mL} / \mathrm{min} . \mathrm{kg}, p<0,0391)$ foram observados no grupo de pacientes obesos, no pós-operatório de revascularização do miocárdio empregando circulação extracorpórea e hipotermia. Os parâmetros farmacocinéticos obtidos poderiam justificar as concentrações plasmáticas do propranolol nos pacientes obesos superiores àquelas obtidas para não obesos após a cirurgia cardíaca.

UNITERMOS: Propranolol. Farmacocinética. Circulação extracorpórea. Obesidade.

\section{ACKNOWLEDGEMENTS}

To the University of Sao Paulo/Pro-Reitoria de Pesquisa: (1) PROJECT 1: 96.1.27884.1.0 and 97.1.27884.1.0, (2) PROJECT 3/PROINTER 96.1.36042.1.0 and to the Brazilian Foundations for Research: FAPESP 00/02707-4 CNPq: 306205/88/96-98, Scientific Cooperation Programme: 99.1.524.9.9 E.J.Zerbini Foundation/InCor-University of Sao Paulo, for the financial support to this project.

\section{REFERENCES}

BABKA, R.; PIFARRÉ, R. Potassium replacement during cardiopulmonary bypass. J. Thorac. Cardiovasc. Surg., St. Louis, v.73, n.2, p.212-215, 1977.

BELFRAGE, E. Vasodilatation and modulation of vasoconstriction in canine subcutaneous adipose tissue caused by activation of $\beta$-adrenoceptors. Acta Physiol. Scand., Stockholm, v. 102, p. 459-468, 1978. 
BOUDOULAS, H.; SNYDER, G.L.; LEWIS, R.P.; KATES, R.E.; KARAYANNACOS, P.E.; VASKO, J.S. Safety and rationale for continuation of propranolol therapy during coronary bypass operation. Ann. Thorac. Surg., Boston, v. 26, n. 3, p. 222-227, 1978.

BRAILLON, A.; CAPRON, J.P. Foie et obesité. Gastroentérol. Clin. Biol., Paris, v. 7, p. 627-634, 1983.

BRAILLON, A.; CAPRON, J.P.; HERVE, M.A.; DEGOTT, C.; QUENUM, C. Liver in obesity. Gut, London, v. 26, p. 133-139, 1985.

BUYLAERT, W.A.; HERREGODS L.L.; MORTIER E.P.; BOGAERT, M.G. Cardiopulmonary bypass and the pharmacokinetics of drugs. An update. Clin. Pharmacokinet., Auckland, v. 17, n. 1, p. 10-26, 1989.

CHEYMOL, G.; POIRIER, J.M.; BARRE, J.; PRADALIER, A.; DRY, J. Comparative pharmacokinetics of intravenous propranolol in obese and normal volunteers. J. Clin. Pharmacol., New York, v. 27, n. 11, p. $874-879,1987.0$

CHEYMOL, G.; POIRIER, J.M.; CARRUPT, P.A.; TESTA, B.; WEISSENBURGER, J.; LEVRON, J.C.; SNOECK, E. Pharmacokinetics of beta-adrenoceptor in obese and normal volunteers. Br. J. Clin. Pharmacol., London, v. 43 , n. 6 , p. 563-570, 1997.

FELLANDER, G.; ELEBORG, L.; BOLINDER, J.; NORDENSTRON, J.; ARNER, P. Microdialysis of adipose tissue during surgery: effect of local alpha- and beta-adrenoceptor blockade on blood flow and lipolysis. J. Clin. Endocrinol. Metab., Baltimore, v. 81, n. 8, p. 2919-2924, 1996.

HOFFMAN, B.B.; LEFKOWITZ, R.J. Catecholamines, sympathomimetic drugs, and adrenergic receptor antagonists. In: HARDMAN J.G.; LIMBIRD L.E.; MOLINOFF, P.B.; RUDDON, R.W.; GILMAN, A.G., eds, Goodman \& Gilman's The pharmacological basis of therapeutics. 9.ed. New York: McGraw Hill, 1996. cap. 10, p. 235-237, 1776.

HOLLEY, F.O.; PONGANIS, K.V.; STANSKI, D.R. Effect of cardiopulmonary bypass on the pharmacokinetics of drugs. Clin. Pharmacokinet., Auckland, v. 7, n. 3, p. 234$251,1982$.
JONES, E.L.; KAPLAN, J.A.; DORNEY, E.R.; KING, S.B.; DOUGLAS, J.S.J.R.; HATCHER, C.R.J.R. Propranolol therapy in patients undergoing myocardial revascularization. Am. J. Cardiol., Belle Mead, v. 38, p. 696-700, 1976.

MCALLISTER, R.G.J.R.; TAN, T.G. Effect of hypothermia on drug metabolism. In vitro studies with propranolol and verapamil. Pharmacology, Basel, v. 20, n. 2, p. 95-100, 1980.

MCALLISTER, R.G.; BOURNE, D.W.; TAN, T.G.; ERIKSON, J.L.; WACHTEL, C.C.; TODD, E.P. Effects of hypothermia on propranolol kinetics. Clin. Pharmacol. Ther., St Louis, v. 25, n. 1, p. 1-7, 1979.

PDR. Generics. 52.ed. Montvale: Medical Economics, 1998. p. 3046.

POIRIER, J.M.; LE JEUNNE, C.; CHEYMOL, G.; COHEN, A.; BARRE, J.; HUGUES, F.C. Comparison of propranolol and sotalol pharmacokinetics in obese subjects. J. Pharm. Pharmacol., London, v. 42, n. 5, p. 344-348, 1990.

PEREIRA, V.A.; BERTOLINE, M.A.; CARMONA, M.J.C.; AULER JÚNIOR, J.O.C.; SANTOS, S.R.C.J. High performance liquid chromatography to determine propranolol in plasma. Drug accumulation in postsurgical patients. Rev. Bras. Ciênc. Farm., São Paulo, v. 36, p. 241-247, 2000.

SAGER, G.; JAEGER, R.; LITTLE, C. Binding of prazosin and propranolol at variable a1-acid glycoprotein and albumin concentrations. Br. J. Clin. Pharmacol., London, v. 27, n. 2 , p. $229-234,1989$.

WEISS, Y.A.; SAFAR, M.E.; LEHNER, J.P.; LEVENSON, J.A.; SIMON, A.; ALEXANDRE, J.M. (+) Propranolol clearance, an estimation of hepatic blood flow. Br. J. Clin. Pharmacol., London, v. 5, p. 457-460, 1978.

Recebido para publicação em 30 de agosto de 2002. 